\title{
Water Use and Productivity of Different Agricultural and Horticultural Crops and Rice and Maize-based Cropping Systems in an Intensively Cultivated Sub-watershed of Peninsular India
}

\author{
M. Uma Devi ${ }^{1}$, M. Devender $\operatorname{Reddy}^{2}$, A. Mani $^{3}$, D. V. Mahalakshmi ${ }^{*}$ and O. Bhavani ${ }^{1}$ \\ ${ }^{1}$ Water Technology Centre, Professor Jayashankar Telangana State Agricultural University, \\ Rajendranagar, Hyderabad, India \\ ${ }^{2}$ M.S.Swaminathan School of Agriculture, Centurion University of technology and \\ Management, Parlakhemundi, Odisha, India \\ ${ }^{3}$ College of Agricultural Engineering, Acharya N.G. Ranga Agricultural University, Bapatla, \\ Andhra Pradesh, India \\ ${ }^{4}$ Land and Atmospheric Physics Division (LAPD), Earth and Climate Sciences Area \\ (ECSA), National Remote Sensing Centre (NRSC), ISRO, Hyderabad \\ *Corresponding author
}

\section{A B S T R A C T}

\begin{tabular}{l} 
Key w or d s \\
Cropping system, \\
Horticultural crops, \\
Maize, Rice, \\
Vegetable, Water \\
productivity, \\
Watershed \\
\hline $\begin{array}{l}\text { Article Info } \\
\text { Accepted: } \\
\text { 12 September } 2020 \\
\text { Available Online: } \\
10 \text { October } 2020\end{array}$ \\
\hline
\end{tabular}

The crop water requirement of different agricultural and horticultural crops (16 crops) was assessed during different season's viz., kharif, rabi and summer for four successive years (2008-12) in farmers field conditions. The water utilized and water productivity of rice -rice and maize - vegetable cropping systems were studies at Wargal, Kothakunta sub -watershed, in Siddipet district, Telangana. The mean water used and water productivity of crops was estimated for kharif rice $\left(13299 \mathrm{~m} 3 / \mathrm{ha}\right.$ and $\left.0.457 \mathrm{~kg} \mathrm{~m}^{-3}\right)$, rabi rice $\left(14298 \mathrm{~m} 3 / \mathrm{ha}\right.$ and $\left.0.463 \mathrm{~kg} \mathrm{~m}^{-3}\right)$, maize $\left(3472 \mathrm{~m} 3 / \mathrm{ha}\right.$ and $\left.1.607 \mathrm{~kg} \mathrm{~m}^{-3}\right)$, sweet corn $(3378 \mathrm{~m} 3 / \mathrm{ha}$ and 1.812 $\mathrm{kg} \mathrm{m}^{-3}$ ), cotton $\left(5421 \mathrm{~m} 3 / \mathrm{ha}\right.$ and $\left.1.61 \mathrm{~kg} \mathrm{~m}^{-3}\right)$, sunflower $\left(9209 \mathrm{~m} 3 / \mathrm{ha}\right.$ and $\left.0.051 \mathrm{~kg} \mathrm{~m}^{-3}\right)$, tomato (drip irrigation) $\left(5162 \mathrm{~m} 3 / \mathrm{ha}\right.$ and $\left.1.544 \mathrm{~kg} \mathrm{~m}^{-3}\right)$, tomato (surface irrigation) $\left(11665 \mathrm{~m} 3 / \mathrm{ha}\right.$ and $\left.1.376 \mathrm{~kg} \mathrm{~m}^{-3}\right)$, bhendi (surface irrigation) $\left(9302 \mathrm{~m} 3 / \mathrm{ha}\right.$ and $\left.0.464 \mathrm{~kg} \mathrm{~m}^{-3}\right)$, green chillies (surface irrigation) $(7597 \mathrm{~m} 3 / \mathrm{ha}$ and $2.22 \mathrm{~kg} \mathrm{~m}^{-3}$ ), French bean (surface irrigation) (kharif- $3704 \mathrm{~m} 3 / \mathrm{ha}$ and $0.99 \mathrm{~kg} \mathrm{~m}^{-3}$, rabi-2846 m3/ha and $0.94 \mathrm{~kg} \mathrm{~m}^{-3}$ and summer- $4972 \mathrm{~m} 3 / \mathrm{ha}$ and $\left.0.887 \mathrm{~kg} \mathrm{~m}^{-3}\right)$. French bean (drip irrigation) $(2626 \mathrm{~m} 3 / \mathrm{ha}$ and $\left.1.347 \mathrm{~kg} \mathrm{~m}^{-3}\right)$, French bean (after paddy) surface irrigation $\left(2751 \mathrm{~m} 3 / \mathrm{ha}\right.$ and $\left.2.456 \mathrm{~kg} \mathrm{~m}^{-3}\right)$, bush bean (surface irrigation) $\left(6069 \mathrm{~m} 3 / \mathrm{ha}\right.$ and $\left.0.62 \mathrm{~kg} \mathrm{~m}^{-3}\right)$, bush bean (drip) $\left(6088 \mathrm{~m} 3 / \mathrm{ha}\right.$ and $\left.1.005 \mathrm{~kg} \mathrm{~m}^{-3}\right)$, bush bean surface irrigation (after paddy field) $\left(2404 \mathrm{~m} 3 / \mathrm{ha}\right.$ and $0.349 \mathrm{~kg} \mathrm{~m}^{-3}$ ), vegetable cow pea (drip irrigation) rabi $\left(9713 \mathrm{~m} 3 / \mathrm{ha}\right.$ and $\left.0.696 \mathrm{~kg} \mathrm{~m}^{-3}\right)$, vegetable cow pea (drip irrigation) summer (4040m3/ha and $\left.1.19 \mathrm{~kg} \mathrm{~m}^{-3}\right)$, ridge gourd (drip irrigation) (5334 m3/ha and $\left.1.413 \mathrm{~kg} \mathrm{~m}^{-3}\right)$, cabbage (surface irrigation) $\left(6802 \mathrm{~m} 3 / \mathrm{ha}\right.$ and $\left.11.92 \mathrm{~kg} \mathrm{~m}^{-3}\right)$, ), cucumber ( (drip irrigation) (kharif-3304 m3/ha and $1.599 \mathrm{~kg} \mathrm{~m}^{-3}$, rabi$2241 \mathrm{~m} 3 / \mathrm{ha}$ and $2.67 \mathrm{~kg} \mathrm{~m}^{-3}$ and summer- $10048 \mathrm{~m} 3 / \mathrm{ha}^{-3}$ and $0.782 \mathrm{~kg} \mathrm{~m}^{-3}$ ), onion (surface irrigation) (2136 $\mathrm{m} 3 / \mathrm{ha}$ and $2.676 \mathrm{~kg} \mathrm{~m}^{-3}$ ), potato (surface irrigation) (4386 m3/ha and $2.396 \mathrm{~kg} \mathrm{~m}^{-3}$ ), potato (drip irrigation) $\left(4621 \mathrm{~m} 3 / \mathrm{ha}\right.$ and $\left.3.509 \mathrm{~kg} \mathrm{~m}^{-3}\right)$. The rice crop consumed a higher quantity of water than other crops. The cabbage cultivated during rabi 2009-10 under surface irrigation recorded the highest water productivity, while the lowest water productivity was recorded in sunflower during rabi 2011-12.Rice equivalent yield was worked out using prevailing crop market prices during 2009-12. Mean water productivity of different rice-rice and maize based cropping systems was found to be rice -rice $\left(0.38 \mathrm{~kg} \mathrm{~m}^{-3}\right)$, maize -potato $(0.76 \mathrm{~kg}$ $\left.\mathrm{m}^{-3}\right)$, maize - tomato $\left(0.86 \mathrm{~kg} \mathrm{~m}^{-3}\right)$, maize- fallow -French bean $\left(0.89 \mathrm{~kg} \mathrm{~m}^{-3}\right)$, maize - vegetable cow pea $\left(0.57 \mathrm{~kg} \mathrm{~m}^{-3}\right)$, maize- fallow - bush bean $\left(1.33 \mathrm{~kg} \mathrm{~m}^{-3}\right)$ and maize - cabbage $\left(2.31 \mathrm{~kg} \mathrm{~m}^{-3}\right)$. The water productivity of maize - vegetable cropping system was three times higher than that of rice - rice cropping system. Therefore, from the present study maize - vegetable cropping system was found to be the most viable cropping system under Wargal, Kothakunta sub -watershed for conservation of available water resources. 


\section{Introduction}

In India more than $80 \%$ of the water resources are used for agriculture. The agriculture sector uses a higher quantity of water and in the coming years it has to compete with other sectors like domestic, industry and power generation and the share of water available for agricultural production is getting reduced day by day. The groundwater contributes more than $60 \%$ of the irrigated area in India. To meet the food grain requirement of people, it is assumed that the overall irrigation efficiencies will be in the order of $50 \%$ for surface water systems and $72 \%$ for groundwater systems, compared to the level of 35-40\% in 2010 (FAO, 2010). For feeding the growing population with decreased water allocation for agriculture, that is, to increase agricultural water productivity. The water productivity (WP) is a measure of the ability of agricultural systems to convert water into food (Kijne et al., 2003). It can be measured as physical and economic WP, irrigation and rainwater productivity (Simon Cook et al., 2006).In general, the WP in farmer's fields is low as compared to experimental sites indicating the need for more efforts to transfer water-saving technologies (Yadvinder-Singh et al., 2014). With scientific data on crop water requirements in different seasons and for producing targeted yields, the regional planning of water resources could be achieved. In Wargal, Kothakunta sub watershed, 206 bore wells irrigate 192.91 ha and the crops cultivated under bore wells are paddy, maize, vegetables, cotton and sunflower. The major area is under rice. Rice consumes a large quantity of water and the productivity is lower than any irrigated dry crop. Alternatives for increasing water productivity can be applied at the crop, farm system and basin levels (Molden et al., 2001). The knowledge of water resources availability, crop water requirement and water productivity is necessary for its improvement especially in groundwater extracted areas. Hence, an attempt was made during 2008 to 2012 to assess the water productivity of different agricultural and horticultural crops and rice -rice and maize - vegetable based cropping systems in Kothakunta sub watershed in Siddipet district of Telangana, India that helps to suggest alternative agronomic measures for increasing the water productivity.

\section{Materials and Methods}

The Wargal village is located at latitude $17^{0}$ 41'19.4' $\mathrm{N}$, longitude $78^{\circ} 29^{\prime} 24.0^{\prime}$ ' $\mathrm{E}$ and an elevation of $576-590 \mathrm{~m}$ above sea level in Siddipet district of Telangana. Wargal village is having 2618 ha of geographical area with 1460 ha rain-fed, 167 ha under tank irrigation and 235 ha under irrigation of 206 bore wells. The major crops cultivated under bore wells include paddy, maize, vegetables (bhendi, beans, potato, ridge guard, onion and cowpea), cotton and sunflower. Though the village is having red chalka (Red sandy/sandy clay loams - Alfisols, 2336 ha) and black cotton soils (Vertisols, 280 ha), the watershed area (about $15 \mathrm{sq} \mathrm{km}$ ) consists of mostly red soils. The area is having a slope of $1-5 \%$, with shallow to medium soil depth and coarse to medium in soil texture. The soil is having a $\mathrm{pH}$ range of 6.5 to 7.5 , low in available $\mathrm{N}$, low to high in available phosphorus and medium to high in available $\mathrm{K}$. The major amount of rainfall is received during the South-West monsoon and the normal rainfall is $773 \mathrm{~mm}$. The land holdings indicate that $25 \%, 47 \%$ and $28 \%$ of the farmers belonged to marginal, small and large (Vijayakumari et al., 2012).

The water use and water productivity of different agricultural and horticultural crops were assessed during kharif, rabi and summer seasons for four successive years. The water used and water productivity of rice -rice and 
maize - vegetable based cropping systems were worked out. The crops were grown with groundwater irrigation in Wargal subwatershed. The popular rice varieties like BPT 5204, JGL 384, Kaveri and Prabhala 1101 and hybrid maize and high yielding vegetable varieties were grown during kharif and rabi seasons. Data was recorded on the quantity of water used and yield of the different crops from the farmer's fields. Growing the crops with surface irrigation was prevalent in the watershed area. Drip irrigation facility was provided to four farmers of the village and crop water requirement under drip irrigation was recorded along with surface irrigation. The irrigation water given to crops was measured by fixing water meters to water delivery pipe and the quantity of water applied at each irrigations was recorded.

Amount of rainfall received differed considerably year to year. It was $662 \mathrm{~mm}, 489$ $\mathrm{mm}, 1081 \mathrm{~mm}$ and $570 \mathrm{~mm}$ during 2008, 2009, 2010 and 2011 year, respectively. The rainfed crops grown during kharif crops were given supplemental irrigations and the rice in kharif and rabi and rabi irrigated dry crops were cultivated with groundwater of bore wells. The total water received for each crop was estimated by adding the irrigation water given through bore well and the effective rainfall. The rice equivalent yield was calculated by estimating the total value of different crops and back converting to paddy based on the prevailing prices of the product during the crop season viz., rice (kharif) Rs $12.4 \mathrm{~kg}^{-1}$, rice (rabi) Rs $8.8 \mathrm{~kg}^{-1}$, maize Rs 8.8 $\mathrm{kg}^{-1}$, sweet corn Rs $13 \mathrm{~kg}^{-1}$, tomato Rs 3.43 $\mathrm{kg}^{-1}$, potato Rs $5.48 \mathrm{~kg}^{-1}$, cabbage Rs 1.70 $\mathrm{kg}^{-1}$, green chilli Rs $11.8 \mathrm{~kg}^{-1}$, beans Rs 10.2 $\mathrm{kg}^{-1}$, cucumber (rabi) Rs $2.36 \mathrm{~kg}^{-1}$, cucumber (summer) Rs $6.41 \mathrm{~kg}^{-1}$, ridge gourd Rs 13.6 $\mathrm{kg}^{-1}$, bhendi Rs $7.5 \mathrm{~kg}^{-1}$ and vegetable cowpea Rs $5.6 \mathrm{~kg}^{-1}$.Water productivity (WP) (kg grain $\mathrm{m}^{-3}$ of water) was calculated for individual crops and rice equivalent yield as shown below:

1. Water productivity $=$ (for individual crops)

Yield $\left(\mathrm{kg} \mathrm{ha}^{-1}\right)$ Amount of water used $\left(\mathrm{m}^{3}\right)$

2. Water productivity (for rice equivalent yield) $=$ $\frac{Y}{\mathrm{IR}+\mathrm{R})}$

Where

$Y=$ rice equivalent yield $\left(\mathrm{kg} \mathrm{ha}^{-1}\right)$ and

$\mathrm{IR}=$ Irrigation water $\left(\mathrm{mm}\right.$ or $\left.\mathrm{m}^{3}\right)$

$\mathrm{R}=$ Effective rain fall $\left(\mathrm{mm}\right.$ or $\mathrm{m}^{3}$ )

$(\mathrm{IR}+R)=$ total water input

$\mathrm{IR}=$ irrigation water

$\mathrm{R}=$ effective rainfall

Effective rainfall data was arrived using CRIWAR software.

$$
\text { 3. Rice equivalent yield }(\mathrm{kg} / \mathrm{ha})=\quad \begin{aligned}
& \text { Yield of the particular crop }(\mathrm{kg} / \mathrm{ha}) \mathrm{x} \\
& \text { price of the crop }(\mathrm{Rs} / \mathrm{kg})
\end{aligned}
$$

\section{Results and Discussion}

Yield, water use, water requirement and water productivity of different agricultural and horticultural crops cultivated in Kothakunta sub watershed is presented in Table 1 and Fig. 1.

\section{Rice}

The grain yield of rice ranged from 4987 to $6093 \mathrm{~kg} / \mathrm{ha}$ with a mean of $5442 \mathrm{~kg} / \mathrm{ha}$ during kharif and 5982 to $6085 \mathrm{~kg} / \mathrm{ha}$ with a mean of $6034 \mathrm{~kg} / \mathrm{ha}$ during rabi (2008-10). The rice crop grown during rabi $(6034 \mathrm{~kg} / \mathrm{ha})$ recorded $6 \%$ higher yield than kharif crop (5442 $\mathrm{kg} / \mathrm{ha}$ ). The highest water consumption and water requirement was recorded in rice crop. The water used by the rice crop ranged from 8388 to $17032 \mathrm{~m} 3 / \mathrm{ha}$ with a mean of 13299 $\mathrm{m} 3 /$ ha during kharif and 11612 to 16983 $\mathrm{m} 3 /$ ha with a mean of $14298 \mathrm{~m} 3 / \mathrm{ha}$ during 
rabi. The water requirement of rice crop ranged from 1631 to $2833 \mathrm{~L} / \mathrm{kg}$ with a mean of $2188 \mathrm{~L} / \mathrm{kg}$ during kharif and 1842 to 2611 $\mathrm{L} / \mathrm{kg}$ with a mean of $2160 \mathrm{~L} / \mathrm{kg}$ during rabi. The water productivity of rice ranged from 0.353 to $0.613 \mathrm{~kg} / \mathrm{m} 3$ with a mean of 0.457 $\mathrm{kg} / \mathrm{m} 3$ during kharif and 0.383 to $0.543 \mathrm{~kg} / \mathrm{m} 3$ with a mean of $0.463 \mathrm{~kg} / \mathrm{m} 3$ during rabi.

\section{Maize}

The yield of maize grown during kharif varied from 2589 to $7250 \mathrm{~kg} / \mathrm{ha}$ with a mean of 5420 $\mathrm{kg} / \mathrm{ha}$. The water used by the maize ranged from 1840 to $4230 \mathrm{~m} 3 / \mathrm{ha}$ with a mean of $3472 \mathrm{~m} 3 / \mathrm{ha}$, whereas its water requirement ranged from 515 to $739 \mathrm{~L} / \mathrm{kg}$ with a mean of $597 \mathrm{~L} / \mathrm{kg}$. The water productivity of maize varied from 1.353 to $1.942 \mathrm{~kg} / \mathrm{m} 3$ with a mean of $1.607 \mathrm{~kg} / \mathrm{m} 3$.

\section{Maize (Sweet corn)}

The sweet corn was cultivated during kharif and its grain yield ranged from 3125 to 7261 $\mathrm{kg} / \mathrm{ha}$ with a mean of $5193 \mathrm{~kg} / \mathrm{ha}$. Its fresh weight was $10161 \mathrm{~kg} / \mathrm{ha}$. The maize sweet corn used water ranging from 2516 to 4240 $\mathrm{m} 3 /$ ha with a mean of $3295 \mathrm{~m} 3 / \mathrm{ha}$ and its water requirement ranged from 308 to 1357 $\mathrm{L} / \mathrm{kg}$ with a mean of $670 \mathrm{~L} / \mathrm{kg}$. Its water productivity ranged from 0.737 to 3.246 $\mathrm{kg} / \mathrm{m} 3$ with a mean of $2.289 \mathrm{~kg} / \mathrm{m} 3$. Among cereals rice crop grown during rabi consumed higher quantity of water and sweet corn cultivated during kharif recorded higher water productivity.

\section{Cotton}

Cotton was cultivated during kharif and recorded a yield of $2425 \mathrm{~kg} / \mathrm{ha}$. The water requirement of cotton was $621 \mathrm{~L} / \mathrm{kg}$ and it used $5421 \mathrm{~m} 3 / \mathrm{ha}$ water. It recorded a water productivity of $1.61 \mathrm{~kg} / \mathrm{m} 3$.

\section{Sunflower}

The seed yield of sunflower grown during rabi was $471 \mathrm{~kg} / \mathrm{ha}$. The sunflower used 9209 $\mathrm{m} 3 / \mathrm{ha}$ water and its water requirement was $19608 \mathrm{~L} / \mathrm{kg}$. The water productivity of sunflower was $0.051 \mathrm{~kg} / \mathrm{m} 3$.

\section{Vegetables}

In Kothakunta sub-watershed, data was recorded for vegetables cultivated under surface irrigation and drip irrigation.

\section{Tomato}

The tomato cultivated under drip irrigation during rabi recorded a fresh fruit yield of $6498 \mathrm{~kg} / \mathrm{ha}$. The fresh fruit yield of tomato cultivated under surface irrigation during rabi was $16053 \mathrm{~kg} / \mathrm{ha}$. The water used by the tomato cultivated under drip irrigation was $5162 \mathrm{~m} 3 /$ ha and its water requirement was $648 \mathrm{~L} / \mathrm{kg}$. The tomato cultivated under surface irrigation used $11665 \mathrm{~m} 3 / \mathrm{ha}$ water and its water requirement was $727 \mathrm{~L} / \mathrm{kg}$. The tomato cultivated under drip irrigation recorded $6 \%$ higher water productivity than surface irrigation.

\section{Bhendi}

The yield of bhendi cultivated under surface irrigation during kharif was $4317 \mathrm{~kg} / \mathrm{ha}$. The water used and water requirement of the bhendi was $9302 \mathrm{~m} 3 / \mathrm{ha}$ and $2155 \mathrm{~L} / \mathrm{kg}$, respectively. The water productivity of bhendi was $0.464 \mathrm{~kg} / \mathrm{m} 3$.

\section{Green chillies}

Green chillies cultivated during summer to kharif under surface irrigation recorded fresh green chillies yield ranging from 6402 to $24986 \mathrm{~kg} / \mathrm{ha}$ with a mean of $15694 \mathrm{~kg} / \mathrm{ha}$. Green chillies water used ranged from 6791 to 
$8403 \mathrm{~m} 3 /$ ha with a mean of $7597 \mathrm{~m} 3 / \mathrm{ha}$ and its water requirement ranged from 272 to $1312 \mathrm{~L} / \mathrm{kg}$ with a mean of $450 \mathrm{~L} / \mathrm{kg}$. Green chillies recorded water productivity ranging from 0.762 to $3.679 \mathrm{~kg} / \mathrm{m} 3$ with a mean of $2.22 \mathrm{~kg} / \mathrm{m} 3$.

\section{French bean}

The French bean cultivated under surface irrigation during kharif recorded fresh pod yield of $3667 \mathrm{~kg} / \mathrm{ha}$. The fresh pod yield of French bean ranged from 1663 to $2340 \mathrm{~kg} / \mathrm{ha}$ with a mean of $2001 \mathrm{~kg} / \mathrm{ha}$ during rabi and 3057 to $5000 \mathrm{~kg} / \mathrm{ha}$ with a mean of 4029 $\mathrm{kg} / \mathrm{ha}$ during summer. However, the fresh pod yield of French bean cultivated under drip irrigation during summer was $3537 \mathrm{~kg} / \mathrm{ha}$ and French bean grown after paddy under surface irrigation during rabi was $6757 \mathrm{~kg} / \mathrm{ha}$. The water used by the French bean under surface irrigation was $3704 \mathrm{~m} 3 / \mathrm{ha}$ during kharif and ranged from 1662 to $4031 \mathrm{~m} 3 /$ ha with a mean of $2846 \mathrm{~m} 3 / \mathrm{ha}$ during rabi. The water requirement of the French bean was 1010 $\mathrm{L} / \mathrm{kg}$ during kharif and ranged from 770 to $1721 \mathrm{~L} / \mathrm{kg}$ with a mean of $1245.5 \mathrm{~L} / \mathrm{kg}$ during rabi. During summer French bean recorded water usage of 3960 to $5984 \mathrm{~m} 3 /$ haand a water requirement of 792 to $1957 \mathrm{~L} / \mathrm{kg}$ with a mean of $4972 \mathrm{~m} 3 / \mathrm{ha}$ and $1127 \mathrm{~L} / \mathrm{kg}$, respectively. However, water used by the French bean cultivated under drip irrigation during summer was $2626 \mathrm{~m} 3 /$ ha with a water requirement of $742 \mathrm{~L} / \mathrm{kg}$. French bean grown after paddy under surface irrigation during rabi used water of $2751 \mathrm{~m} 3 /$ ha with a water requirement of $407 \mathrm{~L} / \mathrm{kg}$. The water productivity of French bean was $0.99 \mathrm{~kg} / \mathrm{m} 3$ during kharif and ranged from 0.581 to 1.299 $\mathrm{kg} / \mathrm{m} 3$ with a mean of $0.94 \mathrm{~kg} / \mathrm{m} 3$ during rabi. It recorded water productivity ranging from 0.511 to $1.263 \mathrm{~kg} / \mathrm{m} 3$ with a mean of 0.887 $\mathrm{kg} / \mathrm{m} 3$ during summer. The water productivity of French bean cultivated under drip irrigation during summer was $1.347 \mathrm{~kg} / \mathrm{m} 3$ and French bean grown after paddy under surface irrigation during rabi was $2.456 \mathrm{~kg} / \mathrm{m} 3$.

\section{Bush bean}

The fresh pod yield of bush bean cultivated under drip irrigation during summer ranged from 4019 to $7635 \mathrm{~kg} / \mathrm{ha}$ with a mean of 5827 $\mathrm{kg} / \mathrm{ha}$. The yield of bush bean grown under surface irrigation during summer ranged from 2186 to $5500 \mathrm{~kg} / \mathrm{ha}$ with a mean of 3843 $\mathrm{kg} / \mathrm{ha}$. The yield of bush bean was higher under drip irrigation than surface irrigation. The bush bean grown after paddy during summer recorded a yield of $840 \mathrm{~kg} / \mathrm{ha}$. The water used by the bush bean cultivated under surface irrigation ranged from 5757 to 6380 $\mathrm{m} 3 /$ ha with a mean of $6069 \mathrm{~m} 3 / \mathrm{ha}$ and its water requirement ranged from 1161 to 2639 $\mathrm{L} / \mathrm{kg}$ with a mean of $1613 \mathrm{~L} / \mathrm{kg}$. The water used by the bush bean grown under drip irrigation ranged from 5384 to $6791 \mathrm{~m} 3 / \mathrm{ha}$ with a mean of $6088 \mathrm{~m} 3 / \mathrm{ha}$ and its water requirement ranged from 705 to $1689 \mathrm{~L} / \mathrm{kg}$ with a mean of $995 \mathrm{~L} / \mathrm{kg}$. The bush bean grown after paddy used $2404 \mathrm{~m} 3 /$ ha water with a water requirement of $2865 \mathrm{~L} / \mathrm{kg}$. The water productivity of bush bean under drip irrigation ranged from 0.592 to $1.418 \mathrm{~kg} / \mathrm{m} 3$ with a mean of $1.005 \mathrm{~kg} / \mathrm{m} 3$. The water productivity of bush bean under surface irrigation ranged from 0.379 to $0.861 \mathrm{~kg} / \mathrm{m} 3$ with a mean of $0.62 \mathrm{~kg} / \mathrm{m} 3$. Therefore, the water productivity of bush bean was $24 \%$ higher under drip irrigation than surface irrigation. The bush bean grown after paddy recorded a water productivity of $0.349 \mathrm{~kg} / \mathrm{m} 3$.

\section{Vegetable cowpea}

The fresh pod yield of vegetable cowpea grown during rabi under drip irrigation was $6764 \mathrm{~kg} / \mathrm{ha}$. Vegetable cowpea cultivated during summer recorded fresh pod yield of $4809 \mathrm{~kg} / \mathrm{ha}$. The water used by the vegetable cowpea grown during rabi was $9713 \mathrm{~m} 3 / \mathrm{ha}$ 
and water requirement was $1437 \mathrm{~L} / \mathrm{kg}$. During summer its water usage was $4040 \mathrm{~m} 3 / \mathrm{ha}$, whereas its water requirement was $840 \mathrm{~L} / \mathrm{kg}$.
The water productivity of vegetable cowpea was $0.696 \mathrm{~kg} / \mathrm{m} 3$ during $r a b i$ and $1.19 \mathrm{~kg} / \mathrm{m} 3$ during summer.

Table.1 Yield, water used, water productivity and water requirement of different crops grown in farmer's field conditions at Kothakunta Watershed, Wargal, Medak district

\begin{tabular}{|c|c|c|c|c|c|c|c|}
\hline $\begin{array}{l}\text { Sl. } \\
\text { No. }\end{array}$ & Crops & Season / Year & $\begin{array}{l}\text { Yield } \\
\left(\operatorname{kg~ha}^{-1}\right)\end{array}$ & $\begin{array}{l}\text { Water used } \\
\left(\mathrm{m}^{3} \mathrm{ha}^{-1}\right)\end{array}$ & $\begin{array}{l}\text { Water } \\
\text { Productivity } \\
\left(\mathrm{kg} \mathrm{m}^{-3}\right)\end{array}$ & $\begin{array}{l}\text { Water } \\
\text { Productivity } \\
\left(\mathrm{kg} \mathrm{mm}^{-1}\right)\end{array}$ & $\begin{array}{l}\text { Water } \\
\text { requirement } \\
\text { (litres } \mathbf{~ k g}^{-1} \text { ) }\end{array}$ \\
\hline \multirow[t]{10}{*}{1} & \multicolumn{5}{|c|}{ RICE (Kharif) } & & \\
\hline & 1 & Kharif, 2008 & $6093(4)$ & $17032(4)$ & $0.390(4)$ & 3.9 & 2564 \\
\hline & 2 & Kharif 2009 & $5148(4)$ & $15805(4)$ & $0.353(4)$ & 3.53 & 2833 \\
\hline & 3 & Kharif 2010 & $5538(4)$ & $11970(4)$ & $0.471(4)$ & 4.71 & 2123 \\
\hline & 4 & Kharif 2011 & $4987(3)$ & $8388(3)$ & $0.613(3)$ & 6.13 & 1631 \\
\hline & & Mean & $5442(15)$ & $13299(15)$ & $0.457(15)$ & 4.57 & 2188 \\
\hline & \multicolumn{5}{|c|}{ RICE (Rabi) (Grain yield) } & & \\
\hline & 5 & Rabi 2008-09 & $6085(4)$ & $11612(4)$ & $0.543(4)$ & 5.43 & 1842 \\
\hline & 6 & Rabi 2009-10 & $5982(2)$ & $16983(2)$ & $0.383(2)$ & 3.83 & 2611 \\
\hline & & Mean & $6034(6)$ & $14298(6)$ & $0.463(6)$ & 4.63 & 2160 \\
\hline \multirow[t]{6}{*}{2} & \multicolumn{7}{|c|}{ MAIZE (Kharif) (Grain yield) } \\
\hline & 7 & Kharif 2008 & $7082(4)$ & $3716(4)$ & $1.942(4)$ & 19.42 & 515 \\
\hline & 8 & Kharif 2009 & $4919(3)$ & $4101(3)$ & $1.353(3)$ & 13.53 & 739 \\
\hline & 9 & Kharif 2010 & $7250(2)$ & $4230(2)$ & $1.727(2)$ & 17.27 & 579 \\
\hline & 10 & Kharif 2011 & $2589(2)$ & $1840(2)$ & $1.407(2)$ & 14.07 & 711 \\
\hline & & Mean & $5420(11)$ & $3472(11)$ & $1.607(11)$ & 16.07 & 597 \\
\hline \multirow[t]{5}{*}{3} & \multicolumn{7}{|c|}{ MAIZE (SWEET CORN) (Grain yield) } \\
\hline & 11 & Kharif 2009 & $7261(1)$ & $2516(1)$ & $2.886(1)$ & 28.86 & 347 \\
\hline & 12 & Kharif 2010 & $3125(1)$ & $4240(1)$ & $0.737(1)$ & 7.37 & 1357 \\
\hline & 13 & $\begin{array}{l}\text { Kharif } 2011 \text { (Fresh } \\
\text { weight) }\end{array}$ & $10161(1)$ & $3130(1)$ & $3.246(1)$ & 32.46 & 308 \\
\hline & & Mean & & $3295(3)$ & $2.289(3)$ & 22.89 & 670 \\
\hline \multirow[t]{2}{*}{4} & COTT & & & & & & \\
\hline & 14 & Kharif 2011 & $2425(1)$ & $5421(1)$ & $1.61(1)$ & 6.54 & 621 \\
\hline \multirow[t]{3}{*}{5} & \multicolumn{7}{|c|}{ SUNFLOWER (DRIP) } \\
\hline & 15 & Rabi 2011-12 & $471(1)$ & $9209(1)$ & $0.051(1)$ & 0.51 & 19608 \\
\hline & \multicolumn{5}{|c|}{ VEGETABLES } & & \\
\hline \multirow[t]{3}{*}{6} & \multicolumn{7}{|c|}{ TOMATO (Fresh Fruit yield) } \\
\hline & 16 & $\begin{array}{l}\text { Rabi 2008-09 } \\
\text { (Drip) }\end{array}$ & $6498(3)$ & $5162(3)$ & $1.544(3)$ & 15.44 & 648 \\
\hline & 17 & Rabi 2009-10 (SI) & $16053(1)$ & $11665(1)$ & $1.376(1)$ & 13.76 & 727 \\
\hline \multirow[t]{2}{*}{7} & \multicolumn{7}{|c|}{ BHENDI (SI) } \\
\hline & 18 & Kharif 2011 & $4317(1)$ & $9302(1)$ & $0.464(1)$ & 46.4 & 2155 \\
\hline \multirow[t]{4}{*}{8} & \multicolumn{7}{|c|}{ GREEN CHILLIES (SURFACE IRRIGATION)(Fresh green chillies yield) } \\
\hline & 19 & $\begin{array}{l}\text { Summer } 2010 \text { to } \\
\text { Kharif } 2010\end{array}$ & $6402(1)$ & $8403(1)$ & $0.762(1)$ & 7.62 & 1312 \\
\hline & 20 & $\begin{array}{l}\text { Summer } 2011 \text { to } \\
\text { Kharif } 2011\end{array}$ & $24986(1)$ & $6791(1)$ & $3.679(1)$ & 36.79 & 272 \\
\hline & & Mean & $15694(2)$ & $7597(2)$ & $2.22(2)$ & 22.2 & 450 \\
\hline
\end{tabular}




\begin{tabular}{|c|c|c|c|c|c|c|c|}
\hline \multirow[t]{2}{*}{9} & \multicolumn{7}{|c|}{ FRENCH BEAN (SURFACE IRRIGATION) (Fresh Pod yield) } \\
\hline & 21 & Kharif 2011 & $3667(1)$ & $3704(1)$ & $0.990(1)$ & 9.9 & 1010 \\
\hline & 22 & Rabi 2010-11 & $2340(1)$ & $4031(1)$ & $0.581(1)$ & 5.81 & 1721 \\
\hline & 23 & Rabi 2011-12 & $1663(3)$ & $1662(3)$ & $1.299(1)$ & 12.99 & 770 \\
\hline & & Mean & 2001 & 2846 & 0.94 & 9.4 & 1245.5 \\
\hline & 24 & Summer 2009 & $5000(1)$ & $3960(1)$ & 1.263 & 12.63 & 792 \\
\hline & 25 & Summer 2010 & $3057(1)$ & $5984(1)$ & 0.511 & 5.11 & 1957 \\
\hline & & Mean & $4029(2)$ & $4972(2)$ & $0.887(2)$ & 8.87 & 1127 \\
\hline & \multicolumn{7}{|c|}{ FRENCH BEAN (DRIP) (Fresh pod yield) } \\
\hline & 26 & Summer 2010 & $3537(1)$ & $2626(1)$ & $1.347(1)$ & 13.47 & 742 \\
\hline & \multicolumn{7}{|c|}{ FRENCH BEAN (AFTER PADDY) SURFACE IRRIGATION } \\
\hline & 27 & Rabi 2011-12 & $6757(1)$ & $2751(1)$ & $2.456(1)$ & 24.56 & 407 \\
\hline 10 & \multicolumn{7}{|c|}{ BUSH BEAN (SURFACE IRRIGATION) (Fresh pod yield) } \\
\hline & 28 & Summer 2010 & $2186(2)$ & $5757(2)$ & $0.379(2)$ & 3.79 & 2639 \\
\hline & 29 & Summer 2011 & $5500(2)$ & $6380(2)$ & $0.861(2)$ & 8.61 & 1161 \\
\hline & & Mean & $3843(4)$ & $6069(4)$ & $0.62(4)$ & 6.2 & 1613 \\
\hline & \multicolumn{7}{|c|}{ BUSH BEAN (DRIP) (Fresh pod yield) } \\
\hline & 30 & Summer 2009 & $4019(1)$ & $6791(1)$ & $0.592(1)$ & 5.93 & 1689 \\
\hline & 31 & Summer 2010 & $7635(1)$ & $5384(1)$ & $1.418(1)$ & 14.18 & 705 \\
\hline & & Mean & $5827(2)$ & $6088(2)$ & $1.005(2)$ & 10.05 & 995 \\
\hline & \multicolumn{7}{|c|}{ BUSH BEAN (SURFACE IRRIGATION) (Fresh pod yield) (After paddy field) } \\
\hline & 32 & Summer 2011 & $840(1)$ & $2404(1)$ & 0.349 & 3.49 & 2865 \\
\hline 11 & \multicolumn{7}{|c|}{ VEGETABLE COW PEA (DRIP) (LOWA) (Fresh pod yield) } \\
\hline & 33 & Rabi 2009-10 & $6764(1)$ & $9713(1)$ & $0.696(1)$ & 6.96 & 1437 \\
\hline & 34 & Summer 2009 & $4809(1)$ & $4040(1)$ & $1.19(1)$ & 11.9 & 840 \\
\hline 12 & \multicolumn{7}{|c|}{ RIDGE GOURD (DRIP) } \\
\hline & 35 & Summer 2011 & $7537(1)$ & $5334(1)$ & $1.413(1)$ & 14.13 & 708 \\
\hline 13 & \multicolumn{7}{|c|}{ CABBAGE (SURFACE IRRIGATION) (Fresh cabbage yield) } \\
\hline & 36 & Rabi 2009-10 & $81050(1)$ & $6802(1)$ & $11.92(1)$ & 119.2 & 84 \\
\hline 14 & \multicolumn{7}{|c|}{ CUCUMBER (DRIP) (Salad) (Fresh cucumber yield) } \\
\hline & 37 & Kharif 2011 & $5285(1)$ & $3304(1)$ & $1.599(1)$ & 15.99 & 625 \\
\hline & 38 & Rabi 2011-12 & $5983(1)$ & $2241(1)$ & $2.67(1)$ & 26.7 & 375 \\
\hline & 39 & Summer 2011 & $7859(1)$ & $10048(1)$ & $0.782(1)$ & 7.82 & 1279 \\
\hline 15 & \multicolumn{7}{|c|}{ ONION (SI) } \\
\hline & 40 & Kharif 2011 & $5714(1)$ & $2136(1)$ & $2.676(1)$ & 26.76 & 374 \\
\hline 16 & \multicolumn{7}{|c|}{ POTATO (SURFACE IRRIGATION) (Tuber yield) } \\
\hline & 41 & Rabi 2008-09 & $4809(1)$ & $4000(1)$ & $1.202(1)$ & 12.02 & 832 \\
\hline & 42 & Rabi 2009-10 & $3034(2)$ & $7417(2)$ & $0.514(2)$ & 5.14 & 1946 \\
\hline & 43 & Rabi 2010-11 & $9750(1)$ & $1754(1)$ & $5.559(1)$ & 55.59 & 180 \\
\hline & 44 & Rabi 2010-11 & $10095(1)$ & $4371(1)$ & $2.309(1)$ & 23.09 & 433 \\
\hline & & Mean & $6922(5)$ & $4386(5)$ & $2.396(4)$ & 23.96 & 417 \\
\hline & \multicolumn{7}{|c|}{ POTATO (DRIP IRRIGATION) (Tuber yield) } \\
\hline & 45 & Rabi 2009-10 & $2298(1)$ & $8473(1)$ & $0.271(1)$ & 27.1 & 3690 \\
\hline & 46 & Rabi 2010-11 & $14750(3)$ & $2639(3)$ & $7.802(3)$ & 78.02 & 128 \\
\hline & 47 & Rabi 2011-12 & $6757(1)$ & $2751(1)$ & $2.456(1)$ & 24.56 & 407 \\
\hline & & Mean & $7935(5)$ & $4621(5)$ & $3.509(5)$ & 35.09 & 285 \\
\hline
\end{tabular}

Figures in parentheses indicate the number of farmers 
Table.2 Rice equivalent yields ( $\mathrm{kg} / \mathrm{ha})$, water used and water productivity of different cropping systems of Kothakunta sub watershed, Wargal, Siddipet district, Telangana

\begin{tabular}{|c|c|c|c|c|c|c|c|c|c|c|}
\hline $\begin{array}{l}\text { Sl. } \\
\text { No. }\end{array}$ & $\begin{array}{l}\text { Cropping } \\
\text { system }\end{array}$ & \multicolumn{4}{|c|}{$\begin{array}{c}\text { Rice equivalent yield (REY) of } \\
\text { system, } \\
\text { Kg/ha }\end{array}$} & \multicolumn{4}{|c|}{$\begin{array}{l}\text { Mean Water consumed by system } \\
\mathbf{m}^{3} / \mathrm{ha}\end{array}$} & $\begin{array}{c}\text { Water } \\
\text { Productivit } \\
\text { y of the } \\
\text { system, } \\
\text { REY kg/m }{ }^{-3}\end{array}$ \\
\hline \multicolumn{11}{|c|}{ 2008-09 } \\
\hline & & Kharif & Rabi & Summer & Total & Kharif & Rabi & Summer & Total & \\
\hline 1 & Rice - rice & 6093 & 6085 & - & 12178 & 17032 & 11612 & - & 28644 & 0.43 \\
\hline 2 & Maize -potato & 5077 & 2995 & - & 8072 & 3716 & 4000 & - & 7716 & 1.05 \\
\hline 3 & Maize -Tomato & 5077 & 2533 & - & 7610 & 3716 & 5162 & - & 8878 & 0.86 \\
\hline 4 & $\begin{array}{l}\text { Maize- Fallow - } \\
\text { French bean }\end{array}$ & 5077 & - & 4113 & 9190 & 3716 & - & 3960 & 7676 & 1.20 \\
\hline 5 & $\begin{array}{l}\text { Maize- Fallow - } \\
\text { bush bean }\end{array}$ & 5077 & - & 3306 & 8383 & 3716 & - & 6791 & 10507 & 0.80 \\
\hline \multicolumn{11}{|c|}{ 2009-10 } \\
\hline 1 & Rice -rice & 5148 & 5982 & - & 11130 & 15805 & 16983 & - & 32788 & 0.34 \\
\hline 2 & Maize -potato & 3527 & 1889 & - & 5416 & 4101 & 7417 & - & 11518 & 0.47 \\
\hline 3 & $\begin{array}{l}\text { Maize- Fallow - } \\
\text { French bean }\end{array}$ & 3527 & - & 2515 & 6042 & 4101 & - & 5984 & 10085 & 0.60 \\
\hline 4 & $\begin{array}{l}\text { Maize - } \\
\text { vegetable cow } \\
\text { pea }\end{array}$ & 3527 & 4304 & - & 7831 & 4101 & 9713 & - & 13814 & 0.57 \\
\hline 5 & $\begin{array}{l}\text { Maize- Fallow - } \\
\text { bush bean }\end{array}$ & 3527 & & 6280 & 9807 & 4101 & - & 5384 & 9485 & 1.03 \\
\hline 6 & Maize-Cabbage & 4577 & 11112 & & 15689 & 4101 & - & 6802 & 10903 & 2.31 \\
\hline
\end{tabular}

Fig.1 Mean water productivity of different cropping systems $\left(\mathrm{REY} \mathrm{kg} / \mathrm{m}^{3}\right)$ in Wargal,

Siddipet district, Telangana, during 2008-09 and 2009-10

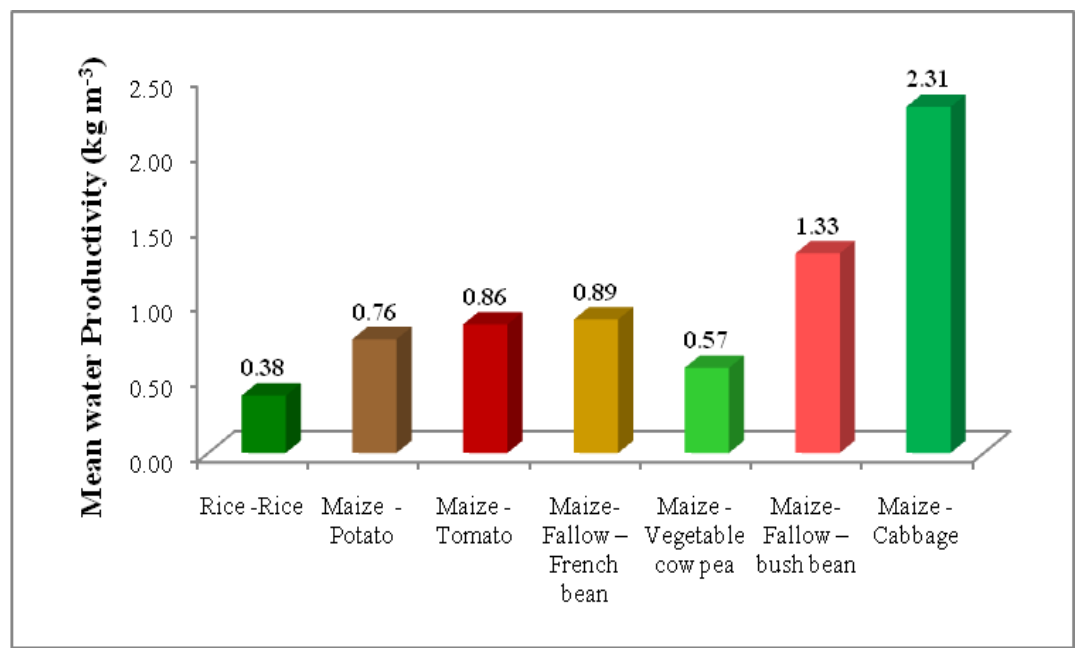




\section{Ridge gourd}

The ridge gourd cultivated under drip irrigation during summer recorded $7537 \mathrm{~kg} / \mathrm{ha}$ yield. The ridge gourd used $5334 \mathrm{~m} 3 / \mathrm{ha}$ water and its water requirement was $708 \mathrm{~L} / \mathrm{kg}$. Water productivity of ridge gourd was 1.413 $\mathrm{kg} / \mathrm{m} 3$.

\section{Cabbage}

The fresh cabbage yield cultivated under surface irrigation during rabi was 81050 $\mathrm{kg} / \mathrm{ha}$. The water used by the cabbage was $6802 \mathrm{~m} 3 / \mathrm{ha}$ and its water requirement was 84 $\mathrm{L} / \mathrm{kg}$. The water productivity of cabbage was $11.92 \mathrm{~kg} / \mathrm{m} 3$.

\section{Cucumber}

The yield of cucumber cultivated under drip irrigation during kharif was $5285 \mathrm{~kg} / \mathrm{ha}$, rabi was $5983 \mathrm{~kg} / \mathrm{ha}$ and summer was $7859 \mathrm{~kg} / \mathrm{ha}$. The water usage and water requirement of the cucumber during kharif was $3304 \mathrm{~m} 3 / \mathrm{ha}$ and $625 \mathrm{~L} / \mathrm{kg}$, rabi was $2241 \mathrm{~m} 3 / \mathrm{ha}$ and $375 \mathrm{~L} / \mathrm{kg}$ and summer was $10048 \mathrm{~m} 3 / \mathrm{ha}$ and $1279 \mathrm{~L} / \mathrm{kg}$, respectively. The water productivity of cucumber during kharif was $1.599 \mathrm{~kg} / \mathrm{m} 3$, rabi was $2.67 \mathrm{~kg} / \mathrm{m} 3$ and summer was 0.782 $\mathrm{kg} / \mathrm{m} 3$.

Among different vegetables cabbage (11.92 $\mathrm{kg} / \mathrm{m} 3$ ) cultivated under surface irrigation recorded the highest water productivity and bush bean $(0.349 \mathrm{~kg} / \mathrm{m} 3)$ cultivated under surface irrigation after paddy recorded the lowest water productivity. The water productivity of the vegetables grown under drip irrigation was higher than surface irrigation. Under drip irrigation potato cultivated during rabi recorded the highest water productivity $(3.509 \mathrm{~kg} / \mathrm{m} 3)$.

\section{Onion}

The onion cultivated under surface irrigation during kharif recorded a yield of $5714 \mathrm{~kg} / \mathrm{ha}$.
The onion used $2136 \mathrm{~m} 3 / \mathrm{ha}$ water and its water requirement was $374 \mathrm{~L} / \mathrm{kg}$. It recorded a water productivity of $2.676 \mathrm{~kg} / \mathrm{m} 3$.

\section{Potato}

The tuber yield of potato cultivated under drip irrigation during rabi ranged from 2298 to $14750 \mathrm{~kg} / \mathrm{ha}$ with a mean of $7935 \mathrm{~kg} / \mathrm{ha}$, whereas the yield of potato grown under surface irrigation during rabi ranged from 3034 to $10095 \mathrm{~kg} / \mathrm{ha}$ with a mean of 6922 $\mathrm{kg} / \mathrm{ha}$. Therefore, potato cultivated under drip irrigation $(7935 \mathrm{~kg} / \mathrm{ha})$ recorded higher tuber yield than surface irrigation $(6922 \mathrm{~kg} / \mathrm{ha})$. The potato cultivated under drip irrigation used water ranging from 2639 to $8473 \mathrm{~m} 3 / \mathrm{ha}$ and its water requirement ranged from 128 to $3690 \mathrm{~L} / \mathrm{kg}$ with a mean of $4621 \mathrm{~m} 3 / \mathrm{ha}$ and $285 \mathrm{~L} / \mathrm{kg}$, respectively. The potato cultivated under surface irrigation used water ranging from 1754 to $7417 \mathrm{~m} 3 / \mathrm{ha}$ and its water requirement ranged from 180 to $1946 \mathrm{~L} / \mathrm{kg}$ with a mean of $4386 \mathrm{~m} 3 / \mathrm{ha}$ and $417 \mathrm{~L} / \mathrm{kg}$, respectively. The water productivity of potato cultivated under drip irrigation ranged from 0.271 to $7.802 \mathrm{~kg} / \mathrm{m} 3$ with a mean of 3.509 $\mathrm{kg} / \mathrm{m} 3$, whereas the water productivity of potato under surface irrigation ranged from 0.514 to $5.559 \mathrm{~kg} / \mathrm{m} 3$ with a mean of 2.396 $\mathrm{kg} / \mathrm{m} 3$. Therefore, potato cultivated under drip irrigation $(3.509 \mathrm{~kg} / \mathrm{m} 3)$ recorded $18 \%$ higher water productivity than surface irrigation (2.396 kg/m3).

\section{Rice-rice and maize -vegetable based cropping systems}

\section{Rice equivalent yield (REY)}

For comparison, the yields of different crops were converted to rice equivalent yield (REY). The REY of the rice -rice cropping system was $12178 \mathrm{~kg} / \mathrm{ha}$ in the first year (2008-09) and $11130 \mathrm{~kg} / \mathrm{ha}$ in the second year (2009-10) (Table 2). During the first year of 
study, the maize -fallow-French bean recorded higher REY of $9190 \mathrm{~kg} / \mathrm{ha}$ followed by maize -fallow-bush bean $(8383 \mathrm{~kg} / \mathrm{ha})$, maize -potato $(8072 \mathrm{~kg} / \mathrm{ha})$ and maize tomato $(7610 \mathrm{~kg} / \mathrm{ha})$. During the second year of study, the maize -cabbage recorded higher REY of $15689 \mathrm{~kg} / \mathrm{ha}$, while the lower REY was recorded by maize -potato cropping system $(5416 \mathrm{~kg} / \mathrm{ha})$.

\section{Water use of different cropping systems}

The total quantity of water consumed during both years was the highest in rice -rice cropping system (28644 m3/ha and $32788 \mathrm{~m} 3 / \mathrm{ha})$. In the first year water consumed in rice -rice cropping system was $32.99 \%, 31.16 \%, 33.06 \%, 28.59 \%$ higher than maize- potato, maize - tomato, maize fallow-French bean and maize -fallow-bush bean, cropping system respectively. In the second year water consumed in rice -rice cropping system was $24.01 \%, 25.63 \%, 21.42$ $\%, 26.3 \%$ and $24.7 \%$ higher than maizepotato, maize -fallow-French bean, maizevegetable cowpea, maize -fallow-bush bean and maize -cabbage cropping system, respectively (Table 2). However, during second year water used by rice - rice cropping system was higher than that of rice rice cropping system in first year.

\section{Water productivity of different cropping systems}

Among different cropping systems, the lowest water productivity was recorded in rice -rice cropping system during both the years. In first year, maize -fallow-French bean recorded higher water productivity of $1.20 \mathrm{~kg} / \mathrm{m} 3$ followed by maize -potato $(1.05 \mathrm{~kg} / \mathrm{m} 3)$ (Table 2). The maize -tomato and maize fallow-bush bean cropping systems recorded lower water productivity than the former two maize - vegetable cropping systems. In second year, the maize - cabbage cropping system recorded higher water productivity $(2.31 \mathrm{~kg} / \mathrm{m} 3)$ than other systems. The mean water productivity of maize vegetable cropping system was higher than that of rice - rice cropping system (Table 2 and Fig. 1). In general, the rice crop water productivity increases with short duration (Tuong, 1999) and increase in the ratio of photosynthesis to transpiration (Peng et al., 1998). Further, extensive variability in crop water productivity in a region will occur due to many non-climate related parameters which can be managed.

In conclusion the mean water productivity indicated that among cereal crops sweet corn had the highest water productivity. Among vegetables water productivity of cabbage was highest. During kharif sweet corn recorded the highest water productivity, while during rabi cabbage recorded the highest water productivity and during summer green chillies recorded the highest water productivity. In general, crops under drip system recorded higher water productivity than under surface irrigation. The water productivity of the maize - vegetable cropping system was three times greater than that of rice - rice cropping system. In intensively groundwater irrigated area of water-shed, it is advisable to follow maize-based irrigated dry crops rather than rice - rice cropping system for groundwater sustainability in peninsular India where rainfall is an uncertainty and groundwater recharge fluctuates greatly from year to year.

\section{References}

FAO. 2010. AQUASTAT-FAO's global information system on water and agriculture, http://www.fao.org/nr/aquastat.

Molden, D., Sakthivadivel, R., and Habib, Z. 2001. Basin-level use and productivity of water: examples from South Asia. IWMI Research Report 49. 
International Water Management Institute (IWMI), Colombo, Sri Lanka.

Peng, S., Laza, R.C., Khush, G.S., Sanico, A.L., Visperas, R.M., and Garcias, F.V. 1998. Transpiration efficiencies of indica and improved tropical japonica rice grown under irrigated conditions. Euphytica. 103: 103-08.

Simon Cook, Francis Gichuki and Hugh Turral. 2006. Agricultural water productivity: estimation at plot, farm and basin scale. Basin Focal Project Working Paper No. 2. www.waterforfood.org.

Tuong, T.P. 1999. Productive water use in rice production: opportunities and limitations. J. Crop Prod. 2: 241-64.

Van Ittersum, M. K., Leffelaar, P. A., Van
Keulen, H., Kropff, M. J., Bastiaans, L., and Goudriaan, J., 2003. On approaches and applications of the Wageningen crop models. Euro. J. Agron. 18: 20-34.

Vijayakumari, R., Reddy, M.D., Umadevi, M., Mahalakshmi, Rao Mylavarapu and Reddy, G.B. 2012. Socioeconomic status and economics of agriculture in an intensively cultivated watershed of Andhra Pradesh, India.

Kukal, S. S., Yadvinder Singh., Jat, M. L., and Sidhu, H. S. 2014. Improving water productivity of wheat-based cropping systems in south Asia for sustained productivity. Adv.Agron. 127: $157-5$.

\section{How to cite this article:}

Uma Devi, M., M. Devender Reddy, A. Mani, D. V' Mahalakshmi and Bhavani, O. 2020. Water Use and Productivity of Different Agricultural and Horticultural Crops and Rice and Maizebased Cropping Systems in an Intensively Cultivated Sub-watershed of Peninsular India. Int.J.Curr.Microbiol.App.Sci. 9(10): 1273-1283. doi: https://doi.org/10.20546/ijcmas.2020.910.153 